3. Enabling Transboundary Cooperationand Integrated Water Resources Management in the Dniester River Basin: URL: https://www.thegef.org/project/enabling-transboundary-cooperationand-integrated-water-resources-management-dniester-river

4. Пестициди на Львівщині. URL.: http://deplv.gov.ua/pesticidi-nalvivshhini

5. Усе про непридатні пестициди. Київ, МАМА-86. - 2010. - 15 с.

DOI https://doi.org/10.30525/978-9934-26-111-4-21

\title{
MATHEMATICAL MODELING OF RADIONUCLIDE MIGRATION IN FOREST ECOSYSTEMS IN THE CONTEXT OF ACHIEVING THE OBJECTIVES OF GREEN ECONOMY
}

\author{
Raichuk L. A. \\ Ph.D. (Agriculture), Senior Researcher, \\ Head of Department of Radioecology and Remote Sensing of Landscapes \\ Institute of Agroecology and Environmental Management of National \\ Academy of agrarian Sciences of Ukraine
}

\author{
Shvydenko I. K. \\ Ph.D. (Agriculture),
}

Head of the Laboratory of Radioecology of Agrarian and Forest Ecosystems Institute of Agroecology and Environmental Management of National Academy of agrarian Sciences of Ukraine

\author{
Chobotko G. M. \\ Dr.Sc. (Biology), Professor, \\ Leading Researcher
}

Institute of Agroecology and Environmental Management of National Academy of agrarian Sciences of Ukraine

Kyiv, Ukraine

The global trends of recent decades regarding the formation of a «green» narrative in the development of various spheres of public life are becoming increasingly relevant for Ukraine. The green economy has been considered as one of the important tools for sustainable development, which will strengthen the ability of counties to use natural resources rationally with a 
less negative impact on the environment and increase their efficiency. For the effective proceeding of the country to the principles of the green economy, effective political mechanisms must be established, in particular, through the development and implementation of appropriate green economy strategies. Such a strategy for Ukraine should include a comprehensive, integrated approach. Indicators of green growth include, but are not limited to, natural resources, biodiversity and ecosystems (wildlife resources), the nature reserves area, and the number of hunted/red-listed animals. Maintaining ecosystems in their natural state creates conditions for the sustainable provision of «ecosystem services», which currently are not yet taken into account in the economy of Ukraine. Thereby, the rate of biodiversity loss is a matter of concern both nationally and internationally. This is mainly due to human impacts on ecosystem integrity, environmental quality, and biodiversity itself. At the same time, the Law of Ukraine «On Basic Principles (Strategy) of the State Environmental Policy of Ukraine for the Period up to 2020» states that «The share of nature reserves in Ukraine is insufficient and remains much smaller than in most European countries, where the area occupied by nature reserves is on average 20\%.» According to the official data of the Ministry of Ecology and Natural Resources of Ukraine, as of January 1, 2020, the area of the nature reserve fund of Ukraine was only $6.77 \%$ of the country's area [1]. Comparing biodiversity conservation and protection programs implemented in the EU and Ukraine, it should be noted that in Ukraine they are mainly nature-friendly, in contrast to EU programs, where the priority is always biodiversity conservation by preventing, avoiding, and combating hazardous processes and natural and man-made phenomena [3, c. 7]. In EU countries, legal regulation of forest protection regulates the control of pollution, monitoring and environmental assessment of forests, their protection from fires as a key factor of environmental danger, leading to significant damage and destruction of the ecosystem [3, c. 7].

In terms of species diversity, forest ecosystems are perhaps the richest in Ukraine. In terms of forest-land percentage, Ukraine is one of the least forested countries in Europe. In many countries around the world, this index is much higher (forest cover in Finland is $58.9 \%$, in Sweden $-67.7 \%$, in Germany $-29 \%$, in France $-28.7 \%$, in Italy $-21.2 \%$, in Canada $-26,6 \%$, in the USA $-32.7 \%$ ). Among the main factors of deforestation of the territory, the second place after felling is occupied by fires. In Ukraine, forests are very unevenly distributed - mainly in Polissya and the Carpathians. However, Polissya of Ukraine is also the most contaminated with radionuclides due to the Chornobyl accident. Speaking from the perspective 
of environmental safety, forest fires in radioactively contaminated areas are the most dangerous. Due to objective reasons, forests, including those in nature reserves, can deposit radionuclides for many years. In terms of the radiological criticality level, forests occupy the first place, even though today the radiation situation in them is relatively stable and predictable. However, due to, among other things, climate change, the frequency, and scale of forest fires have increased. As a result of such fires, the migration of man-made radionuclides and their removal outside forest ecosystems are being intensified. Forests that deposit $20-100 \%$ of primary radioactive fallout lose the ability to retain radionuclides, which creates a potential radiation hazard for the surrounding areas. This requires a scientifically sound comprehensive analysis of radiocapacity, and hence radiation severity of forest ecosystems of Ukrainian Polissya and necessitates radiation contamination monitoring of forest ecosystem components, radionuclides migration, and their removal outside ecosystems. Thus, this issue requires a comprehensive, large-scale study taking into account the current level and composition of radionuclide pollution, climatic conditions, and landscape structure, as well as the use of modern methods and tools for monitoring and forecasting, such as mathematical modeling.

Many studies by both domestic [2, c. 8] and foreign scientists [4-6] have been devoted to the mathematical modeling of radionuclide migration in forest ecosystems, but in the vast majority of them, the problem was considered for small areas or very specific conditions. Moreover, these works are based on monitoring data from at least 15-20 years ago. Recent local methods of simulation and estimation of ecosystem contamination by radionuclides contain some shortcomings, due to the objective complexity of simulated ecosystems, and delimitations only on certain ecosystem types. In some cases, the cost of person-hours and money to obtain the original data is quite significant. Therefore, our study aimed to develop a mathematical model of ${ }^{137} \mathrm{Cs}$ removal from forest ecosystems of Ukrainian Polissya in the remote period after the Chornobyl accident, which would allow us to plan anti-radiation measures and, consequently, develop a strategy for rehabilitation of radioactively contaminated forests. We considered the landscape of the studied region as a set of macrocompartments (ecosystems). Each of them has its structure and several subtypes depending on the ${ }^{137} \mathrm{Cs}$ migration. Data for the model of radionuclide migration in forest ecosystems was obtained from studies [2, 4-6, 8] and the results of our research in Kyiv, Zhytomyr, Chernihiv, Rivne, and Volyn regions since 1993. The modeling of landscapes is based on a biogeochemical cycle, which takes into account both horizontal and vertical flows of the radionuclide. The model can be 
launched in various mathematical software packages and is therefore designed for a wide range of users. The mathematical model has the form of a first-order partial differential system with constants:

$$
\frac{d Q_{i}}{d t}=\sum_{\substack{i, j=1 \\ i \neq j}}^{N}\left(a_{j i} Q_{j}+a_{i j} Q_{i}\right)+F_{i}(t)-\lambda Q_{i}
$$

where the index $j$ is the number of the ${ }^{137} \mathrm{Cs}$ flow-in compartment; index $i$ is the number of the ${ }^{137} \mathrm{Cs}$ flow-out compartment; $F(t)_{\mathrm{i}}$ is the external source term for the compartment $i\left(\mathrm{Bqm}^{-2} \mathrm{t}^{-1}\right) ; Q i(t)$ is ${ }^{137} \mathrm{Cs}$ content in a compartment with the number $i\left(\mathrm{~Bq} / \mathrm{m}^{2}\right) ; \alpha_{i i}$ is the rate of intercompartment transfer of ${ }^{137} \mathrm{Cs}\left(\mathrm{t}^{-1}\right) ; \lambda$ is the half-life of ${ }^{137} \mathrm{Cs}$. The computer implementation of the model was performed in the MAPLE (version 10). Verification of the model by calculating the relevant statistical indicators revealed a lack of partiality in the assessment and high accuracy of forecasts.

The model maintains an exponential tendency to a slow decline in the ${ }^{137} \mathrm{Cs}$ content in all its compartments, and this decrease is mainly due to the physical decay of the radionuclide. It has been confirmed that forest stands provide stability of radionuclide retention in the small cycle, which prevents vertical ${ }^{137} \mathrm{Cs}$ migration down in the soil profile, and the development of forest litter promotes the deposition of ${ }^{137} \mathrm{Cs}$ in the upper soil horizons, which inhibits its distribution in the ecosystem. In the remote period after the Chornobyl accident, no fundamental differences in the peculiarities of ${ }^{137}$ Cs migration within different types of studied forest ecosystems of Ukrainian Polissya have been revealed. In forest ecosystems, the peculiarities of radionuclide removal depend on the characteristics of plant species. Among the components of forest ecosystems, fungi and lichens are characterized by the highest ${ }^{137} \mathrm{Cs}$ accumulation $(25.1-296.1 \mathrm{kBq} / \mathrm{kg}$ and $32.3-44.1 \mathrm{kBq} / \mathrm{kg}$ respectively). The obtained research results can be the basis for solving problems of minimizing the consequences of the Chornobyl accident for forest ecosystems as well as the target region in general.

\section{References:}

1. Державний кадастр територій та об'єктів природно-заповідного фонду України / Природно-заповідний фонд України. URL: http://pzf.menr.gov.ua/пзф-україни/території-та-об'єкти-пзфукраїни.html (дата звернення 22.06.2021).

2. Прикладная радиоэкология леса: [В.П. Краснов, А.А. Орлов, В.А. Бузун и др.]; под ред. д-ра с.-х. наук В.П. Краснова. - Монография. - Житомир: Полісся, 2007. - 680 с. 
3. Регулювання екологічної безпеки транскордонного регіону в умовах євроінтеграції України (наукова доповідь) / [В.С. Кравців, П.В. Жук, І.А. Колодійчук та ін.]; НАН України. ДУ «Інститут регіональних досліджень імені М.І. Долішнього; [наук. ред. В.С. Кравців]. - Львів, 2015. - 121 с.

4. Mamikhin S.V. A simulation model of 3D migration of Cs-137 in soils / S.V. Mamikhin, W.M. Badawy // Вестник Московского университета (Серия: Почвоведение). - 2011. - № 4. - С. 32-36.

5. Maskalchuk L. (2014). Modeling of ${ }^{137} \mathrm{Cs}$ migration from soil to plants after usage of chemical matters. In World Journal of Nuclear Sciences \& Engineering. Vol. 1, No. 1. P. 1-7.

6. Schell W.R., Linkov I., Remkevich V. et al. (1996). Model-directed sampling in Chernobyl forests: general methodology and 1994 sampling program. In The Science of the Total Environmental. No 180. P. 119-240.

7. Thomas J.W. et al. (1993). Forest Ecosystem Management Assessment: an ecological, economic, and social assessment. U.S. Government Printing Office. Pp.1000.

8. Результаты динамического моделирования радиоэкологической обстановки в Украинском Полесье и сравнение их с данными измерений / И.И. Ясковец, В.А. Гирий, В.А. Онищук, Л.И. Шпинар. Агроекологічний журнал. 2001. № 2. С. 62-67. 